\title{
An Enquiry into Sufi Metaphysics
}

\section{Ezgi Ulusoy Aranyosi}

To cite this article: Ezgi Ulusoy Aranyosi (2012) An Enquiry into Sufi Metaphysics, British Journal for the History of Philosophy, 20:1, 3-22, DOI: 10.1080/09608788.2011.650972

To link to this article: https://doi.org/10.1080/09608788.2011.650972

曲 Published online: 17 Feb 2012.

Submit your article to this journal 2

Џll Article views: 521

4 Citing articles: 1 View citing articles 준 


\title{
ARTICLE
}

\section{AN ENQUIRY INTO SUFI METAPHYSICS ${ }^{1}$}

\author{
Ezgi Ulusoy Aranyosi
}

\begin{abstract}
The fact that Sufi metaphysics is usually taken to be merely the writings of Islamic philosophers, like Ibn al-'Arabi, seems to underestimate the philosophical indications of literary texts in the Sufi tradition. When Sufi literary texts are examined for philosophical content, that content is sought within and through the traditional Sufist approach. However, there appears to be a lack of correspondence between the traditional approach on the main conceptions (of God, of the universe, etc.) in Sufism and what literary texts can offer regarding those, when some literary texts are to be examined in a way in which an underlying philosophical system can be extracted from them. In this article, I present a brief analysis of The Conference of the Birds by Farid ud-Din Attar, one of the most significant works focusing on God and written in Sufi tradition. I suggest an alternative framework for Sufi metaphysics, which overlaps with the metaphysical connotations of The Conference of the Birds, via some Spinozistic ideas on God and on God's relationship to the rest of the universe. Since The Conference of the Birds represents a metaphysical doctrine that is apart from the traditional approach, I argue that we are not justified in thinking that Sufi metaphysics is only what Islamic philosophers have so far offered us.
\end{abstract}

Keywords: Sufi metaphysics; Ibn al-'Arabi; pantheism; Spinozist ontology; Farid ud-Din Attar

\section{WHY AND HOW TO INQUIRE INTO SUFI METAPHYSICS}

The fact that Sufi metaphysics is usually taken to be merely writings of Islamic philosophers, like Ibn al-'Arabi, seems to underestimate the philosophical implications of literary texts in the Sufi tradition. When Sufi literary texts are examined for philosophical content, that content is sought within and through the traditional Sufist approach. However, there appears to be a lack of correspondence between the traditional approach to the main

\footnotetext{
${ }^{1}$ I am grateful to Sandrine Berges, Lars Vinx, Ulrich Steinworth and William Coker for their comments on this article. I am very much indebted to István Aranyosi for his care and diligence in reading the drafts that made the final version possible. I would like to thank John Rogers for his helpful editorial suggestions. I would also like to acknowledge my profound gratitude to Hilmi Yavuz for the fruitful discussions that brought this thesis to its best.
} 
conceptions (of God, of the universe, etc.) in Sufism and what literary texts can offer regarding those, when some literary texts are to be examined in a way in which an underlying philosophical system can be extracted from them. My aim in this article is to reinterpret Sufi metaphysics, via some Spinozistic ideas on God and on God's relationship to the rest of the universe. This approach would provide a new explanatory framework for the mismatches between the traditional approach, like that of Ibn al-'Arabi's, and The Conference of the Birds by Farid ud-Din Attar, one of the most significant works focusing on God and written in Sufi tradition.

My project will proceed in three stages: I will first set forth the traditional approach to Sufi metaphysics. Second, I aim to come up with an analysis of The Conference of the Birds, emphasising its metaphysical connotations. Then, I will present a reading of the relevant aspects of Spinoza's philosophy, which focuses on the debate on pantheism. I will show that this reading captures some metaphysical assumptions that match the plausible alternative interpretation of the above-mentioned literary text. I will suggest that The Conference of the Birds, therefore, represents a metaphysical doctrine that is separate from the traditional approach, i.e. that this interpretation reveals a different viewpoint on the metaphysics of Sufism and of Islamic mysticism, within the same tradition. This suggested explanatory framework will focus on the idea of God as a divine mind, on the background of some Spinozistic ideas. By doing so, I aim to show that we are not justified in thinking that Sufi metaphysics is only what Islamic philosophers have so far offered us.

\section{INTRODUCTION}

Sufism is said to be the religious philosophy of Islam from a broad point of view. $^{2}$ Definitions of Sufism, from metaphorical descriptions to theoretical formulations, vary from source to source. ${ }^{3}$ What is common to all these definitions seems to be that Sufism is a religious attitude with philosophical connotations. The reason why I replace 'philosophy' with 'attitude' is because attitude covers more of what can be extracted from Sufism, since the diversity among philosophical tendencies of different groups ${ }^{4}$ in the one and the same Sufi tradition would not allow us to attribute the same philosophical scope to all Sufis. However, all Sufis have the attitude in common. This attitude of the Sufi can be put in common terms of complete devotion

\footnotetext{
${ }^{2}$ Reynold A. Nicholson, The Mystics of Islam (England: Arkana, 1989) 1.

${ }^{3}$ For example, Martin Lings defines Sufism as 'the vocation and the discipline and the science of plunging into the ebb of one of these waves and being drawn back with it to its Eternal and Infinite Source'; see Lings, What is Sufism? (London: Unwin Hyman Limited, 1981) 11. Another distinguished scholar, Titus Burckhardt, takes Sufism to be the esoteric or inward aspect of Islam; see Burckhardt, Introduction to Sufism (Glasgow: Thorsons, 1995) 15.

${ }^{4}$ See footnotes 4 and 5 for the detailed explanation for the diversity among groups.
} 
to self-contemplation, literary productivity and profound interest in religion. The general doctrine of Sufism, with certain philosophical assumptions, rules out diversities in philosophical beliefs of various groups. Nevertheless, usually, not the attitude, but the general doctrine of Sufism is regarded as the common ground for Sufis' literary works and philosophical writings.

There are two problems that occur with this sort of one-way generalist approach. The first problem is that there are diverse groups ${ }^{5}$ within Sufism, as it is acknowledged by some scholars. ${ }^{6}$ The subtle differences among the understandings of these groups create a substantial difference in their literary tradition, if analysed sufficiently closely. Given the multiplicity in understanding within Sufism, the common one-to-one association between a literary work of a certain understanding in Sufism and the Sufi doctrine in general comes out as weak, even unjustified. Since a literary work in Sufism, then, turns out to be a context-specific piece of work, it cannot be fully examined by appeal to the Sufi doctrine in general. The second problem is the problem of oversimplification in textual analysis. This oversimplification springs from the presupposition that literary works in Sufi tradition are to unfold predominantly through various elements ${ }^{7}$ of Sufi doctrine in general. A one-way analysis as such eventually turns into a task of fitting the literary piece into a doctrinal outfit. In textual analysis, then, a pre-existing scheme $^{8}$ that is formed by such elements excludes any other plausible interpretation.

However, Sufi literature is an exemplary phenomenon concerning how philosophy could be embodied in poetry and prose, as for Sufis, writing

\footnotetext{
${ }^{5}$ There are two levels of diversity among these groups: (1) Diversity according to religious practices. This level of diversity will not concern our discussion, as we focus on written pieces of systematic work that are acknowledged by the greatest scholars of Islamic studies rather than the doctrines of tariqats that are orally transmitted most of the time and designed mainly for religious practice. This diversity, therefore, is not to be considered as a determining factor in our selection of texts to be focused on. (2) Diversity according to the domain in which the Sufi expresses himself. This domain is either philosophy or poetry/prose that embodies a philosophical structure. As the former level of diversity is not applicable to our examination regarding the inefficiency of its divisive criterion for what we desire to inquire about, we take the second level of diversity to be our main line of division.

${ }^{6}$ For example, Idries Shah mentions four orders (the Chisti order, the Qadiri order, the Suhrawardi order and the Naqshbandi order) in Sufi tradition; see The Way of Sufi (London: Penguin Compass, 1990) 125. His classification depends on how Sufis in these groups exhibited differences concerning their exercise of religion. In the same way, Shaykh Fadhlalla Haeri, in The Elements of Sufism (Shaftesbury: Element Books, 1990) 20, adds more orders to these ones: the Rifa'1 order, the Shadili order, the Mevlavi order, the Bektashi order, the Ni'amatullah order, the Tijani order and the Jarrahi order.

${ }^{7}$ These elements come from the theoretical writings in Sufi tradition and shape what we call the Sufi doctrine in general.

${ }^{8}$ This pre-existing scheme I shall call 'the traditional approach', since it consists of main theoretical elements and therefore represents the theoretical aspect of Sufi doctrine in general.
} 
literary texts was a way of reflecting upon their ideas and beliefs. ${ }^{9}$ For a literature of this kind, it looks prejudicial to bind down our textual analysis to a particular, traditional approach. At this point, then, a shift regarding our orientation for textual analysis is called for. In this project, I suggest to move from one of the most famous works of Sufi poetry, The Conference of the Birds by Attar, to a new doctrinal construction that is built upon what, if anything, philosophical can be extracted from the literary work itself.

\section{SUFI METAPHYSICS BY PHILOSOPHERS OF ISLAM}

The most sensible step to take first seems to be elaborating on what we bring an alternative to. As a leading figure in Sufism, Ibn al-'Arabi ${ }^{10}$ is considered as the father of the theoretical aspect of Sufi metaphysics. His writings comprise most of what we can trace back as the source of Sufi metaphysics, even though there are scholars throughout the history who suggested alternative theories. ${ }^{11}$ I will focus on Ibn al-'Arabi, since his theory has been the orthodox view in Sufi tradition. I will try to give a clear picture of Ibn al'Arabi's theory of Sufi metaphysics.

Osman Yahia estimates that Ibn al-'Arabi wrote 700 books, treatises and collections of poetry, out of which there are 400 that we have access to, as of today. ${ }^{12,13}$ In his work Futûhât al-makkiyya, which consists of 17,000

\footnotetext{
${ }^{9}$ Another reason behind the fact that Sufi literature embodies a highly philosophical content may have something to do with the relationship between religion and literature, and its appeal to theory and to practice in Sufi tradition. Religion was prima facie considered to be better grasped as a practice than as a theory. Poetry, then, could satisfy this aspect of religion with its contemplative effect and yet could carry the theoretical aspect of religion, for it aims to emphasise certain elements of their belief systems.

${ }^{10}$ With his full name Muhyi ad-Din Muhammad bin Ali al-Hatimi at-Tai Ibn al-'Arabi, 1165-1240, a Muslim Sufi. He is one of the great Sufis of the Middle Ages (Shah 1990, p. 83). His writings have a profound effect on Sufi tradition, both in literary and philosophical aspects. He is considered one of the greatest Islamic metaphysical thinkers. His works include al-Futuhat al-Makkiyya [the Meccan Revelations] in 37 volumes, containing a full exposition of his Sufi doctrine; Fusus al-Hikam, [Bezels of Wisdom], a summary of the teachings of 28 prophets, from Adam to Muhammad.

${ }^{11}$ For example, Imam-e-Rabbani Mujaddid Alf Sani Shaykh Ahmad al-Faroogi Sirhindi ( 1564 1624) and Shah Waliullah Muhaddith Dehlavi (1703-1762) have different formulations of Sufi metaphysics. The former scholar pointed in Maktoobāt Rabbaniyah that God's existence is greater than the creation and is due to His essence. The latter in his books Lamahat and Sata'at elaborates on Ibn al-'Arabi's philosophy and asserts that Ibn al-'Arabi's 'God is all' refers to the Universal Soul. Dehlavi thinks that God is true reality and that He stands alone with this quality (oneness). That is, Ibn al-'Arabi does not imply anything pantheistic or monistic.

${ }^{12}$ Seven hundred may seem a highly estimated number of written works by Ibn al-'Arabi, however, it must be recognised that the collections of poetry, usually in the form of prayers, and short treatise-like texts (for example, the books Kernel of the Kernel, 48 pages and Whoso Knowth Himself, 27 pages) are also counted within this number. Unedited pieces of manuscripts, maybe some of them constituting books, may allow such a number.

${ }^{13}$ Quoted by William C. Chittick, The Sufi Path of Knowledge: Ibn al-'Arabi's Metaphysics of Imagination (Albany: State University of New York Press, 1989) xi.
} 
pages, ${ }^{14}$ Ibn al-'Arabi discusses a wide range of topics. Above all, we are interested in his ideas on the relationship between God and the world, the structure of the cosmos, the unity of Being and the unity of existence. The theoretical aspect of the work confirms it as the masterpiece of and the guide to Sufi metaphysics. My main focus in this piece is the nature of the unity of Being and of existence in Ibn al-'Arabi's philosophy, as I specifically elaborate upon these concepts, starting below.

Ibn al-'Arabi is taken to be the prime mover of the idea of wahdat al-wujûd, which literally means, unity of creation, of being, of existence. ${ }^{15}$ The meaning of this idea has been controversial, since its prolific content could give rise to as many interpretations as the number of readers. These lexical references of the term wahdat al-wujûd stand as general signifiers for Ibn al-'Arabi's use of the term; however, when we focus on his use, we realise that we have certain limitations in determining the sense of the term. Chittick finds two senses, emerging out of three different translations, of the term in Ibn al-'Arabi's system: (a) Ibn al-'Arabi employs the term as a general one for existence, to refer to the fact that existents share at least one quality, being there in the cosmos. (b) Second, he believes that Ibn al-'Arabi ascribes 'Being' to the term ${ }^{16}$ which refers to God as in Himself. ${ }^{17}$ Considering both uses of the term, the relationship between existence and Being reveals the basic metaphysical foundations of Ibn al-'Arabi's system. This relationship is founded on the idea that existence, namely, the things that exist - the whole cosmos - are spatial and temporal and Being provides the possibility for things to exist, so things exist through Being, ${ }^{18}$ not vice versa. Chittick's and Burckhardt's criticisms ${ }^{19,20}$ of scholars who are tempted to interpret the unity of creation as a pantheistic belief ${ }^{21}$ are fair enough, when Ibn al-'Arabi's formulation of Sufi metaphysics is taken into account. The first point of criticism is by Burckhardt. He believes that 'pantheism only conceives of the relationship between the Divine Principle and things from

\footnotetext{
${ }^{14}$ Idem.

${ }^{15}$ Francis J. Steingass, A Learner's Arabic-English Dictionary (Beirut: Librarie du Liban, 1989) $1192,1201$.

${ }^{16}$ The nuance between 'Being' and existence in Ibn al-'Arabi's terminology is an interesting one. The subtlety here is that Being is associated with characteristics superior to those existence possesses, characteristics such as consciousness, perception and knowledge of the ontological situation. Things, on the other hand, exist in various modes and existence is merely one of their attributes (Chittick 1989, 6).

${ }^{17}$ Chittick (1989) 6.

${ }^{18}$ Ibid., 79.

${ }^{19}$ Idem.

${ }^{20}$ Titus Burckhardt, Introduction to Sufism (Glasgow: Thorsons, 1995) 28-30.

${ }^{21}$ For example, Davis suggests in his introduction to The Conference of Birds a description of Ibn al-'Arabi as 'the Spanish Arab pantheist'; see Farid ud-Din Attar, [1177]. The Conference of the Birds, translated by Afkham Darbandi and Dick Davis (London: Penguin Books, 1984) 12.
} 
the point of view of substantial or existential continuity, and this is an error explicitly rejected by every traditional doctrine. ${ }^{22}$ He continues:

If there were such a continuity by virtue of which God and the manifested universe could be compared as a branch can be compared with the trunk from which it sprang, then this continuity (or what amounts to the same thing), the substance common to the two terms [branch and the trunk, the manifested universe and God] would be either determined by some superior principle which differentiated it or would itself be superior to the two terms which it bound together and, in a sense, included: God would then not be God. $^{23}$

Burckhardt here considers this pantheistic principle of continuity as leading us in two ways. (i) God and the manifested universe both existing in regard of such a continuity would require a superior principle that determines this continuity. This required superior principle would be different than both. (ii) The second option would be that this continuity would itself be superior both to the manifested universe and to God, which would result in destruction of God's superiority to all. Then, God would not be God, indeed.

The second point of criticism is that it is a mistake to take the clay analogy, which compares things to pots of differing form but all made of clay - the famous example that is attributed to Advaita philosophy ${ }^{24}$ reversely. If the totality of material things, namely the unity of existence, is thought to be prior to the essential unity of things, namely the unity of Being, then there is a problem with the causality principle behind the creation. $^{25}$ The difference between the two senses of wahdat al-wujûd, unity of existence and unity of Being, as we pointed out earlier, are confused in this case. Because the clay analogy works with the clay itself and pots of differing shapes that represent the totality of material things, this scheme of the clay analogy can only explain the unity of existence. However, the explananda do not include the Creator, the potter if put in terms of the clay analogy. If the clay analogy is concerned merely with the totality of material things as the unity of existence, then it cannot offer an explanation for God's unity - the unity of Being. Therefore, we are not entitled to shift the unity of existence that is implied in the clay analogy to the unity of Being. Burckhardt develops this criticism into another one that is directed to the metaphysical hierarchy in Sufism. He says:

He recognizes innumerable levels of reality, the hierarchy of which is irreversible, so that one can affirm of the relative that it is in essence one with its

\footnotetext{
${ }^{22}$ Burckhardt (1995) 28.

${ }^{23}$ Idem.

${ }^{24}$ Burckhardt (1995) 29.

${ }^{25}$ Idem.
} 
principle [the ontological cause, independent of its effects] or that it 'is' its principle although one cannot say of the principle that it is included in its product. Thus all beings are God, but God is not all these beings (...). ${ }^{26}$

Because Ibn al-'Arabi's scheme is irreversible in the sense that God is the source that the cosmos emanates from, it is a logical mistake to speak of a one-to-one match between the totality of existents in cosmos and God, the Creator. God is greater than the creation itself and this is not due to a simple sense of exclusion but to a huge difference in degree. Related to this point, Chittick's main criticism against taking Ibn al-'Arabi's philosophy as pantheistic is the following:

God in Himself is Being, and nonexistence has no relationship to Him. That which sets 'everything other than God' apart from God is the admixture of nonexistence. Things, entities, possible things, loci of manifestation, forms, attributes, (...). The things possess certain modes of relative existence, that is existence through the Other, who is God, the Necessary Being. (...) The cosmos is $\mathrm{He} /$ not $\mathrm{He}$. In the context of the philosophical terminology, the basic issue can be phrased in the simple question: 'If God is wujûd, are the things also wujûd?'. The Shaykh [Ibn al-'Arabi] answers that God alone is Being, and the 'existence' of the things is identical to that Being, though the quiddities of the things as quiddities are not Being; in themselves the things are nonexistent. ${ }^{27}$

When all these points of criticism are taken into account, there is no room for monism or pantheism in Sufi metaphysics according to this traditional approach. $^{28}$

On the one hand, the label of pantheism is avoided with the presupposition that materialistic monism is out of question when Quranic values are considered; on the other hand, I believe, the question whether pantheism ${ }^{29}$ is necessarily some sort of materialistic monism ${ }^{30}$ persists. ${ }^{31}$

\footnotetext{
${ }^{26}$ Idem.

${ }^{27}$ Chittick (1989) 79-81.

${ }^{28}$ Panentheism, according to which the creation is in God but still it is not God (G.H.R Parkinson, in Spinoza, B. [1677]. Ethics, edited and translated by G.H.R. Parkinson (New York: Oxford University Press, 2000) 22), is not excluded by some as an alternative. However, according to the traditional approach, the creation with its qualities do belong to Not-He as well (Chittick 1989, 7). Then, panentheism too - at its face value - is not applicable to Sufi metaphysics.

${ }^{29}$ By pantheism, I mean the belief system in which God is regarded as identical to what there is.

${ }^{30} \mathrm{By}$ materialistic monism, I mean the belief system in which there exists only one material substance.

${ }^{31}$ I will get back to this question, when suggesting an alternative view to several conceptions in Sufi metaphysics. I will suggest a different pantheistic reading to the Spinozistic conception of God and of the universe.
} 
When pantheism spells out the motto 'All is God', 32 the general tendency is to take this statement at its face value as 'God is identical to all material existence'. The problem with this inference is that 'all' is taken to be the material existence without further inquiry. We could as well, for all the motto allows, think of 'all' in very different terms. All as both the spiritual ${ }^{33}$ and the material ${ }^{34}$ is a plausible option. ${ }^{35}$ Nevertheless, the plausible materialistic monism as an option that comes along with pantheism places an abyss between Sufism and pantheism per se. Given the metaphysical hierarchy in systems like that of Ibn al-'Arabi's and other Islamic philsophers in the same tradition, this may come out as a fact. Another question, though, perhaps one of vital importance for the discussion, is whether there are any views other than the traditional approach, expressed theoretically or embodied in literary texts, that may be open to different constructions of Sufi metaphysics. I argue that there is. The next part of the project is devoted to the exploration of this matter.

\section{METAPHYSICAL CONNOTATIONS OF THE CONFERENCE OF BIRDS BY ATTAR THE SUFIST}

My plan in this section is to present what The Conference of the Birds as a piece of Sufi literary work can offer philosophically. The metaphorical use of the text is rich in content and complex in terms of the cross-references that

\footnotetext{
32، All is God' is known to be used during the revival of Spinozistic thought among German romantics in nineteenth century. This motto had its original form in Greek at the time: 'Hen kai pan' [One and all]. In Concerning the Doctrine of Spinoza in Letters to Herr Moses Mendelssohn, we see Friedrich Heinrich Jacobi quoting Lessing when Lessing says (to Jacobi) 'I have come to talk to you about my hen kai pan' (Jacobi [1785], The Main Philosophical Writings and the Novel Allwill (Montreal: McGill-Queen's University Press, 1994) 187). This frequently used sentence meant Spinozistic philosophy and pantheism in the same context. However, some, like Toshimasa Yasukata in Lessing's Philosophy of Religion and the German Enlightenment (April 2003, Oxford Scholarship Online Monographs) pp. 117-140, argue that Lessing's thought on Spinoza was more in the direction of panentheism, yet Lessing's relation to pantheism remains open to discussion.

${ }^{33}$ By spiritual, I mean that of non-material.

${ }^{34}$ By material, I mean that of pertaining to the physical sciences. For this way of defining the 'material', see Daniel Stoljar, 'Physicalism', Stanford Encyclopedia of Philosophy. (February 2001, Available from: http://plato.stanford.edu/entries/physicalism).

${ }^{35}$ Here, what I suggest does not have much to do with panentheism (for Parkinson's definition, see footnote 27) in which God is taken to be more than the creation. 'All with both the spiritual and the material content' will not eventually offer a difference in degree but a difference in kind among these contents. I will expand this suggestion in what will follow. Right now, I merely aim to show that the reason Sufism tends to exclude pantheism is pantheism's being taken to be some kind of materialistic monism. I will rule out this exclusion by putting forward a difference between the two. Then, I will present a reading of pantheistic terms that embraces certain principles of Sufism and nevertheless argues for 'All is God.'
} 
end up creating a whole system in which God, the universe and the man seem to be reidentified. I will try to sketch a brief analysis ${ }^{36}$ to uncover this structure. I will base my references on two English translations of the text. One of these translations, by Afkham Darbandi and Dick Davis, is based on the edition of Attar's Manteq at-Tair prepared by Sadegh Gouharin in 1978. The other translation is by C.S. Nott and it is prepared from Garcin de Tassy's nineteenth-century French translation. For a more reliable analysis, I will use both.

Regarding the method of my analysis, I start out with numerical elimination of certain conceptions represented by various metaphors that occur in the text. I focus on the conceptions of God, of man and of universe. If the metaphor relies on a comparison/contrast on any two of these concepts, I prefer to group them and include the related metaphor in one of these specific groups. The numerical information with further details can be found in Table 1.

Throughout the text, there are 105 references to the above-mentioned conceptions which are grouped according to the schools their content falls close to and some of them are in literary forms. The references in the table consist of similes and metaphors, however, it must be noted that the content of figurative language is not oblique, but fairly clear. That is because the use of figurative language is followed by the poet's explicitation of how the metaphor relates to the idea behind it. With this aspect of the work, it becomes possible for the reader to see how wellplaced our listing is.

Given the figures in the table, there are fifty-six references in the text that point out pantheistic conceptions of God and the universe, and this claim must be accounted for. For the sake of keeping in focus, I will discuss the overall narrative in detail and support my inferences from it with other quotations from the text itself. Let us first briefly introduce the overall narrative.

The Conference of the Birds is the story of birds who wish to find their king. After the invocation part, the narrative starts with the hoopoe, the bird that is chosen to lead the others, telling the birds who their king is and what sort of perilous journey they must take if they truly seek him. Some birds find the journey too hard and they tell their leader, the hoopoe, their excuses. The hoopoe's answers and other anecdotes are used to express certain beliefs embedded in the overall narrative, e.g. the excuses by the birds who give up the journey represent the human flaws that are in conflict with the requirements of spiritual fulfilment. At the end, only thirty birds survive, while others either give up or die during the journey, and they get to the gate of God. There they meet Simourgh, which literally means thirty (si)

\footnotetext{
${ }^{36}$ I do not aim for a complete literary examination of the text, nevertheless, my analysis shall reflect upon the text as a whole.
} 


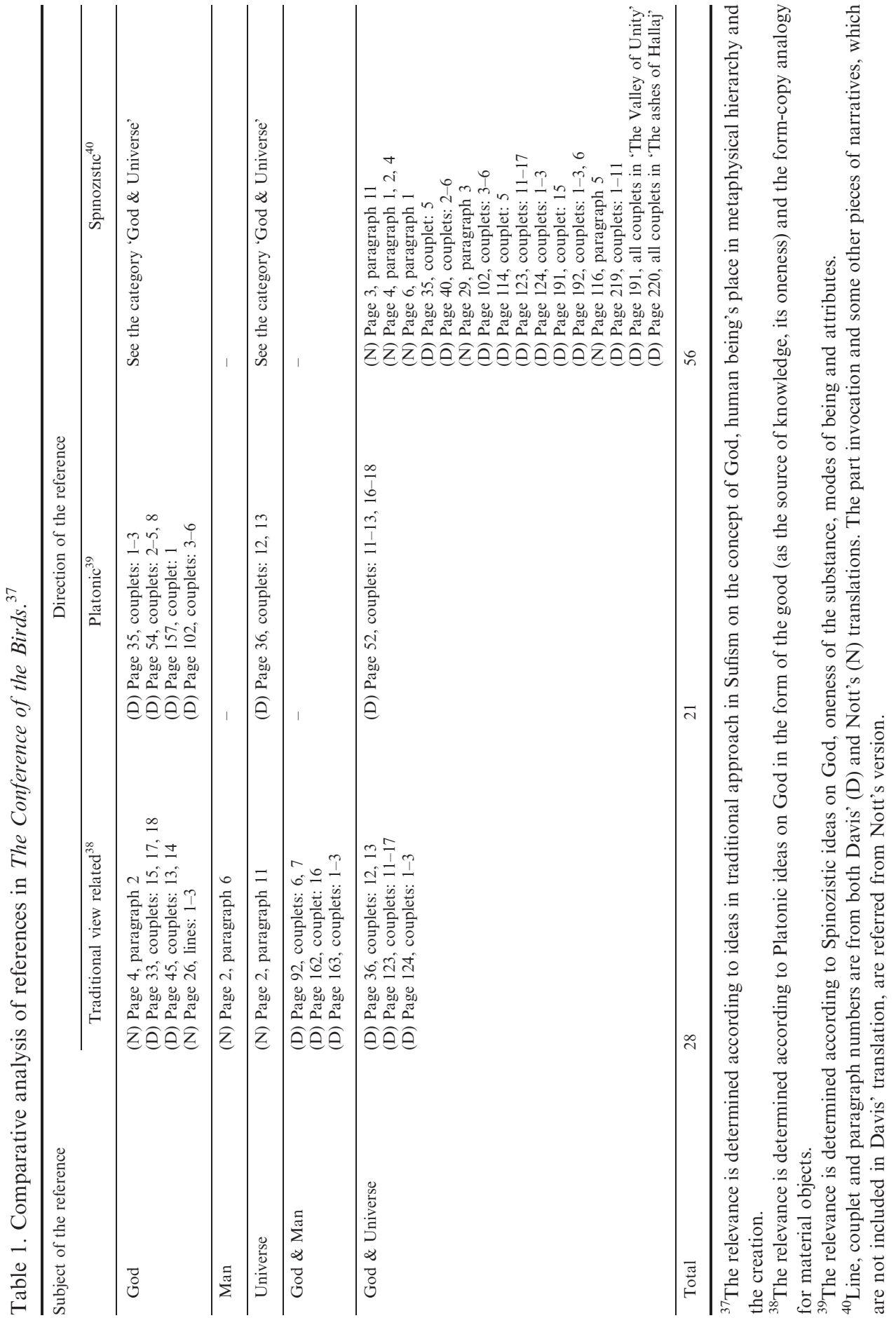


birds (mourgh), and they come to know that Simourgh is actually they themselves.

The end of the story is where the figurative language is demonstrated in one of its strongest uses. When the birds meet God, He answers: '(...) Though you traversed the Valleys' depths and fought/With all the dangers that the journey brought/The journey was in Me, the deeds were Mine - / You slept secure in Being's inmost shrine (...) ${ }^{41}$ In addition to the fact that God is represented as a mirror to whoever could attain the highest stage of mental pilgrimage, God ${ }^{42}$ is vocalised to express the identity between the birds themselves, their deeds and Him. The fact that the journey of pilgrimage $i$ in Him gives a sense of ontological inclusion, that is, the birds, their deeds and their journey is not apart from God Himself. Their existence is included in God's and there remains the identity between thirty birds and Simourgh.

The very next anecdote, after the revelation of the identity between the thirty birds and Simourgh, is about Hallaj, ${ }^{43}$ and this is more than a coincidence. His words 'En el Haqq [I am the Truth]' have been controversial in Sufi tradition and at the time, Hallaj was executed for saying that. Then Attar, when concluding his narrative, recites Hallaj in a way that he supports Simourgh's being indeed thirty birds. Hallaj's attitude is described by him as a prelude, which may suggest that Hallaj was not completely unjustified in saying 'I am the Truth'. When we go back in the text, there are other places where we face some bits that contain descriptive statements of God and the universe. As Attar puts it in the invocation:

God is all, and things have only a nominal value; the world visible and the world invisible are only Himself. (...) There is none but Him. (...) No other than thou [God] is manifested. (...) All see themselves in thee and they see thee in everything. (...) To each atom there is a different door, and for each atom there is a different way which leads to the mysterious Being of whom I speak. $^{44}$

\footnotetext{
${ }^{41}$ Davis (1984) 220.

${ }^{42}$ Here, from a literary analysis point of view, we could argue that this voice heard by the thirty birds when they reached the highest state of spiritual pilgrimage is not necessarily God's. This may well be interpreted as their inner voice, as 'They ask (but inwardly, they make no sound)' how come that they are one with Simourgh, and the Lord replies, again, silently. The way Attar emphasises that this conversation occurs in great silence leads us to this interpretation.

${ }^{43} \mathrm{Al}-\mathrm{Hallaj}$ was a Persian poet, with ties to Sufi doctrine, who was executed for, among other things, crying out 'I am the Truth' while in a state of religious exaltation; see Davis (1984) 220. The word 'Truth' here can also be read as 'God', as the Arabic word haqq has two lexical meanings; see Davis (1984) 13.

${ }^{44}$ C.S. Nott, The Conference of the Birds - A Sufi Fable by Farid ud-Din Attar (Berkeley: Shambala, 1971) 4.
} 
In this passage, there are clues to Attar's ontological assumptions. To start with the two worlds, the visible and the invisible, ${ }^{45}$ the distinction between 'all' and 'all to senses' comes in. The world visible consists of material things, things that are of nominal value. The adjective 'visible' may have been chosen for a couple of reasons: (1) Visibility refers to the sense of sight, which is one of the dominant senses in perception of the environment around us. Hence, the world visible is understood as by its very definition involving the existence of human observers and it is intended to reflect the limitation of their knowledge as compared to divine knowledge. (2) The visible also brings in 'the invisible'. To state a clear epistemic distinction between what is known to us (what is available to our sense-perception) and what is not known to us (what is not available to our sense-perception), the visible-invisible pair seems to fit in firmly regarding Attar's metaphorical use. $^{46}$ The world visible and the world invisible are distinct in this sense, however, it is stated that they - together - are only Himself and there is nothing but Him. There is no denial of God's existence including the world visible, there is only more to it and that is the world invisible. There appears a duality for us, then, the duality between the visible world ${ }^{47}$ and the invisible world. This distinction for us arises from the limits of our understanding. On the other hand, when we speak of God, we speak of a unity of these two worlds ${ }^{48}$ as Him, which is, in itself, available not to our knowledge $^{49}$ but to God's. In His case, there is no duality due to any limitation of knowledge. All-to-God is the mere instantiation of the essential unity of existence as a whole, whereas all-to-us necessarily brings about the duality between the two worlds. In other words, from where we stand, we see the whole existence through this duality; from God's perspective, however, such a duality no longer remains there, for $\mathrm{He}$ is the Knower of all things. Given

\footnotetext{
${ }^{45}$ The reference to the world seen, namely the visible, and the world unseen, namely the invisible, occurs a number of times in the narrative. One of these places is when a man cries for his son's death, saying that he did not see enough of the world. He is replied in the text with the lines, 'If you would take the world with you, you must/Descend with all the world unseen to dust'. Another point is when a fool of God says 'The world, as far as I can see/Is like a box, and we are locked inside'. Both of these uses of the world seen (in the first case, the world that we live in) and the world unseen (in the second case, our limits in this world are emphasised with the box simile, hence the world unseen consists of what is out of the box) are in the same line of emphasis with what is going on in the quoted passage.

${ }^{46}$ The point here is that Attar uses 'the sensible' as a metaphorical reference to the 'the knowable', without claiming that 'the sensible' can be identifiable with 'the knowable'.

${ }^{47}$ The world visible, I shall call from this point on all-to-us, for it refers to what is available to our sense-perception.

${ }^{48}$ The world visible and the world invisible, I shall call from this point on all-to-God, for they refer to more than what is available to our sense-perception, that is the spiritual content of the creation. Only God, Knower of all things, have knowledge of all things from different degrees of existence.

${ }^{49}$ 'God is above and beyond evidence, and nothing can give any idea of his Holy Majesty' with Attar's words; see Nott (1971) p. 4.
} 
this difference in scopes of knowability, ${ }^{50}$ then, duality in unity seems an option to be considered in metaphysical terms of Sufism. At this point, the question is how to fit these two essentially different notions into one system. Before I get to this question towards the end of the project, I will discuss Spinozistic conceptions of God and of the universe depending on textual evidence from his work Ethics. Discussing Spinoza will help me elaborate on certain pantheistic tendencies in his philosophy and relating some of his ideas to my discussion of a plausible pantheistic scheme for Sufi metaphysics.

\section{SPINOZA'S GOD - THE DIVINE MIND AND REFLECTIONS ON SIMOURGH}

Spinoza's philosophy has been interpreted in various ways by philosophers so far. Some of these interpretations radically differ from each other regarding the issue of whether Spinozistic substance monism entails some kind of pantheism. As a result of this divergence in analysis, Spinoza has been labelled a pantheist, ${ }^{51}$ an atheist, ${ }^{52}$ a panentheist ${ }^{53}$ and none of these ${ }^{54}$ at times. In this part of the project, even though it is an

\footnotetext{
${ }^{50}$ The following remark of Chittick's $(1994,16)$ calls for a closer look at the issue: 'It would be a great error to suppose -as some short-sighted critics have supposed - that he simply affirms the oneness of wujud while ascribing the manyness of the cosmos to illusion or human ignorance.' Here we must stress that our picture on the two different scopes of knowability consists not of ontic but of epistemic assumptions. All-to-us is in no case intended to have any implications about the ontic status of the manyness in the physical world, which is 'almost' as real as unity according to Chittick's interpretation of Ibn al-'Arabi. Our distinction does not aim to attempt to solve the problem of duality in unity by ascribing different ontic status to them, it rather tries to do so by examining their epistemic standing that may be giving rise to conceptions such as duality or unity.

${ }^{51}$ Throughout the eighteenth century, German thought that connects to the nineteenth century Romanticism, the admiration of Spinozism was quite common. Goethe (Genevieve Lloyd, Spinoza and the Ethics (London: Routledge, 1996) 15), Lessing (Jacobi, [1785] (1994) 181) and Hegel (Hegel, G.W.F. [1840]. Lectures on the History of Philosophy, translated by R. S. Haldane and Frances H. Simson (London: Routledge \& Kegan Paul - New York: The Humanities Press, 1974, 281-2) are some thinkers who took Spinoza to be a pantheist. Among contemporary philosophers, Jonathan Bennett recognises Spinoza as a pantheist as well; see his 'Spinoza's Monism: A Reply to Curley', in God and Nature: Spinoza's Metaphysics, edited by Yirmiyahu Yovel (Leiden: E.J. Brill, 1991) 58.

${ }^{52}$ For example, Pierre Bayle in his famous Historical and Critical Dictionary depicted Spinoza as an atheist; see Lloyd (1996) 11.

${ }^{53}$ Genevieve Lloyd embraces Martial Guéroult's suggestion that 'panentheism' fits better than 'pantheism' to Spinoza's view of the relation between God and the world; see Lloyd, ibid., 40. ${ }^{54}$ For example, Edwin Curley says that he does not call Spinoza a 'pantheist' in his book Spinoza's Metaphysics; see Edwin Curley, 'On Bennett's interpretation of Spinoza's monism', in God and Nature: Spinoza's Metaphysics, edited by Yirmiyahu Yovel (Leiden: Brill, 1991) 45.
} 
attempt that requires more space than I am permitted to have here, I will argue that Spinoza is a pantheist. Those who have rejected this label for Spinoza so far argued that the Spinozistic conception of God refers to more than the material world; therefore; the case for Spinoza's philosophy is not pantheism but panentheism. I agree with this assumption of theirs, but nevertheless I will go further to conclude otherwise. I will argue that there is at least one case in which panentheism coincides with pantheism: the case in which God is a single infinite mind ${ }^{55}$ that both contains the attributes of thought and of extension and at the same time consists of these attributes. This argumentation will relate to the first two parts of the project in the following way: if there is at least one case in which panentheism coincides with pantheism, then this enables us to consider all-to-us and all-to-God, therefore, the duality in unity in The Conference of the Birds, as possible. Hence, our claim of Sufi metaphysics being not only what Islamic philosophers so far offered us will become justified by this analysis.

Neither doing exegetical work on Spinoza's Ethics nor saying something more than mere exegesis is an easy task. Scholars who attempt to analyse the Ethics are likely to face one evident difficulty: the structure of the text as 'Demonstrated in geometrical order'. Parkinson says this form makes Spinoza's argument seem needlessly long-winded and obscures the nature of his thought. ${ }^{56}$ Another possible consequence, I believe, is that this form allows the reader to focus on the parts as well as on the whole work in its entirety, as the connections and relevant bits are pointed in the text itself precisely by its form. The reader is enabled and even guided by the text to perform partial analysis on the desired subject by tracing back the references to related axioms, definitions, propositions, scholia, etc. This is going to be our method throughout the discussion of Spinozistic conception of God and of God's relation to the rest.

To be able to discuss whether Spinoza was a pantheist or not, we must look at what Spinoza himself has to say about the one basic concept that demarcates the characteristics of any theistic doctrine: God.

By God I understand an absolutely infinite entity, that is, a substance consisting of infinite attributes, each of which expresses eternal and infinite substance. $(\text { E1D6) })^{57}$

\footnotetext{
${ }^{55}$ Keith Ward in his latest book, Pascal's Fire (Oxford: Oneworld Publications, 2006) argues for God as a single infinite mind; however, while his argumentation focuses on the new ways of thinking that seem to be made possible by quantum theory, I will base my version on Spinozistic ideas on God and on the conceptual analysis of how panentheism may ever overlap with pantheism.

${ }^{56}$ Parkinson (2000) 5.

${ }^{57}$ Abbreviations used for Spinoza's Ethics are the following: E=Ethics, D=Definition, $\mathrm{P}=$ Proposition and $\mathrm{S}=$ Scholium.
} 
To see what he means by some elements of this definition, we need to check the definitions of 'attribute' and of 'substance':

By attribute I understand that which intellect perceives of substance, as constituting its essence. (E1D4)

By substance I understand that which is in itself and is conceived through itself; that is, that which does not need the concept of another thing, from which concept it must be formed. (E1D3)

These definitions form the basic aspects of the Spinozistic conception of God, such as its absolute infinity, its independent existence, its existing as one and the only substance and its being expressed by infinite number of attributes. In this picture, so far, God exists alone as a substance that consists of attributes, and these attributes are what is perceived of the substance by the intellect. Substance's priority to its affections, there being only one substance, substance's being a causa sui, infinity of substance, necessity of substance, unity of substance are demonstrated by the propositions 1, 2-5, 6-7, 8, 11 and 13, respectively. It is possible to list other complementary propositions, corollaries and scholia to support these characteristics of the Spinozistic conception of God. Since this kind of analysis would chain us to a merely exegetical endeavour, let us focus on what in Spinoza's Ethics could lead us to portray God as a single infinite mind. ${ }^{58}$

The first occurrence of Spinoza's referring to God as a thinking thing is the second corollary to proposition 14 , which only mentions thought and extension either as attributes of God or as affections of the attributes of God. Some parts of the scholium to proposition 17, however, say a bit more:

(...) the intellect of God, in so far as it is conceived as constituting the essence of God, is truly the cause of things - both of their essence and of their existence. This seems to have been noted by those [e.g. Descartes] ${ }^{59}$ who have asserted that God's intellect, will and power are one and the same. So the intellect of God is the unique cause of things - namely, as we have shown, both of their essence and of their existence - (...). (E1P17S; my emphasis)

In this quotation, Spinoza makes his point by appeal to Descartes' idea that God's intellect, will and power are one and the same. He takes this claim a bit further than that by putting forward an extent: in so far as it (the

\footnotetext{
${ }^{58}$ The reading we will present here could be considered a far cry from the mainstream interpretations of Spinoza. Therefore, this reading is by no means asserted as the right interpretation of Spinozistic philosophy. It rather reflects upon several aspects of Spinozistic thought and remains open to debate, naturally.

${ }^{59}$ This example is given by Parkinson as a footnote to the original text as the following: 'See e.g. Descartes, Principles, I, 23: PWD i. 20I, and Spinoza's geometrical version of the work, PPCIP17C.' (Parkinson 2000, 327)
} 
intellect of God) is conceived as constituting the essence of God. Then, he concludes that the intellect of God is the unique cause of things, both of their essence and of their existence. Besides the immanent (E1P18) causal relation of God to things, the extent to which God's intellect is conceived as constituting the essence of God reveals an identification between God's intellect and God's essence. ${ }^{60}$ Proposition 20 adds to this identity: 'God's existence and his essence are one and the same' (E1P20). Taking these into account, we can form the following argument:

(1) God's intellect constitutes the essence of God. (in E1P17S) ${ }^{61}$

(2) The essence of God and the existence of God are one and the same. (E1P20)

(3) God's intellect constitutes the existence of God. $(1,2)$

(4) God exists as one and the only substance that consists of infinite attributes. (E1P14)

(5) God's intellect constitutes one and the only substance that consists of infinite attributes. $(3,4)$

(6) God's intellect constitutes infinite attributes of the substance. (5, transitivity of identity)

Therefore, God's intellect constitutes God. $(6,4)$

The conclusion of the argument above can equally be expressed in terms of identity. ${ }^{62}$ When constitution as an expression of the identity between the

\footnotetext{
${ }^{60}$ Here. some can argue that $\mathrm{X}$ being constituted by $\mathrm{Y}$ does not entail that $\mathrm{X}$ is identical to $\mathrm{Y}$; however, this seems to be a problem of naming rather than pointing to an invalid shift from 'constitution' to 'identity'. An object $Z$ consisting of atomic particles, say a pen, is still simply called a pen instead of 'object $Z$ - the material entity that is constituted by a number of atomic particles at region $R$ at time $T$, and with even more technical specifications. Hence, in our case, God's intellect that constitutes the essence of God is identical to the essence of God in such a way. Another example could be a 'collection' of books. The total of books constitute a collection and in fact, the total of the books is identical to the collection itself. Here, the relation is not interdependence, so to say, but identity; since the product of constitution equals to the constituter in its totality.

${ }^{61}$ One may object that (E1P17S) is not by itself making a claim as such; however, we must emphasise here that the claim 'God's intellect constitutes the essence of God' is put forward as a condition/premise for the main proposition, 'God alone is a free cause', to work properly. Hence, the use of this premise as a part of Spinozistic thought seems quite legitimate. Another objection may arise by taking what Spinoza says in the same scholium just before 'For the intellect and will which constitute the essence of God would have to differ entirely from our intellect and will, and they could agree with them only in name (no more, in fact than the Dog, the heavenly constellation, agrees with the dog, the animal that barks.)'. Our attempt to regard God as a single infinite mind, as this objection suggests, does not fit with what is said here. However, these words of Spinoza's could be read as merely stating the difference in degree between God's intellect and human intellect. While God's intellect is truly the cause of things, human intellect lacks that kind of potency. Since the extent to which we call God's intellect a mind does not seem to conflict with this difference in degree, naming God's intellect as a single infinite mind is not an issue concerning such an objection.

${ }^{62}$ See footnote 55 .
} 
constituter and the constituted applies to this conclusion, it results in the following: God's intellect is identical to God. God, then, is an infinite mind. ${ }^{63}$

Having argued for God as a single infinite mind, which - as an idea grows out of a Spinozistic root, against other alternatives; now, we shall turn to how this conception of the divine mind reveals the way pantheism and panentheism coincide, and how this framework brings a new alternative to Sufi metaphysics by translating the metaphysical connotations in The Conference of the Birds into a philosophical system.

The picture we have drawn so far reflects God as a single infinite mind - in other words, as constituted by His intellect - that consists of an infinite number of attributes - and we rely on Spinozistic terms to reach this conclusion. In this section, our first objective is to show how the idea that God is a single infinite mind exhibits a pantheistic character in this way. Our second objective is to apply the idea of duality in unity, which we defined when discussing the metaphysical connotations of The Conference of the Birds, to this pantheistic scheme and, therefore, to suggest a new explanatory framework for Sufi metaphysics.

If we take God to be a single infinite mind, then it is apparent that we accept God as a thinking thing. At this point, it becomes crucial to examine the nature of this act of thinking and the relationship between the Thinker and the thought. In particular, we shall aim to reveal the difference in perspective between the scopes of these acts of thinking that are attributed to the human 'I' and the divine 'I' respectively. Let us first take into account a formulation that expresses the human thinking, 'I think (I am a thinking thing)' ${ }^{64}$ From this, we shift to the object ${ }^{65}$ of thinking, which is expressed as the following: 'Then, there is the thought that I think'. Now, all this formulation says is that there is thinking that is ascribed to the subject ' $I$ '. Before arriving at a more general conclusion, let us run this formulation for the case of divine thinking as well: 'I [God] think (God is a thinking thing).', followed by 'Then there is the thought that I [God] think.' for the sake of the shift to the object of thinking. Again, what this formulation emphasises is that there is the act of thinking by the subject that the formulation is uttered by.

The results of such formulations could be run at two levels: (A) At the ontic level: If all that is revealed is the existence of thinking, then we can renounce the subject/predicate duality and commit ourselves to a

\footnotetext{
${ }^{63}$ Even though he gives us neither textual evidence nor any arguments, John Leslie thinks that according to Spinoza, divine thinking is the only reality and our intricately structured universe is an intricate pattern in a divine mind. See Leslie, Immortality Defended (Oxford: Blackwell Publishing, 2007) 36.

${ }^{64}$ This formulation is inspired by Descartes' cogito; however, it has an essentially different claim - as mentioned above - than the Cartesian purpose, namely, proving the indubitable existence of the 'I'.

${ }^{65}$ Here, the term 'object' is used as a primitive notion.
} 
naturalistic position: there is only thinking for granted. ${ }^{66}$ According to this view, the duality between the subject and the predicate vanishes, that is, thinking is the one and the same thing as the subject. As the act of thinking is what grounds the alleged subject to exist in the first place, the naturalist finds no sense to appeal to the existence of a subject as such, and instead takes thinking to be the existent itself. (B) At the epistemic level, the thinking/thought structure persists. This is the panentheistic aspect of the idea of God as a single infinite mind.

Our main claim 'God's intellect constitutes God' reveals a similar type of identity to the one we see in the conclusion (A) that we have drawn above, namely, that of the thinker and the thinking being one and the same thing. If the Thinker (in the divine case) and the thinking is the same, and if the divine thought-patterns that express God's essence (in Spinozistic terms infinite attributes of the substance that are constituted by God's intellect) then all there is is the divine thinking with infinitely many thoughtpatterns. ${ }^{67}$ The uniformity of these thought-patterns as ontologically dependent on one and the only divine thinking, hence, is the whole of existence, (A), and all is both one and in one, as the thought-patterns are both constituting the divine thinking and expressed within the divine thinking, (B). God as a single infinite mind, therefore, is a pantheistic system that subsumes a panentheistic assumption.

Now, let us relate this scheme to the idea of duality in unity that is extracted from The Conference of the Birds. The idea of duality in unity as an outcome of the distinction between all-to-us and all-to-God, of which there are reflections in Attar's use of metaphors throughout the text, springs from the different scopes of knowability. If God as the divine thinking contemplates an infinite number of things, then all-to-God is the thoughtpatterns of this infinite contemplation. God's thought patterns, in other words, are the world visible and the world invisible, if put in Attarian terms. From God's perspective, as it were, the unity of existence (of the worlds visible and invisible) is provided through His very thinking serving as the substrate for infinite number of divine thought patterns. All-to-us, as what we have direct knowledge of, on the contrary, are the things which we, by the limits of understanding, cannot contemplate. The duality for human understanding is apparent at this point, whereas there is only unity in the case of God's infinite contemplation, because God's thinking as the centre of the infinite thought-patterns unifies all. God's existence as a single infinite mind, then, resolves the seeming tension of 'the duality in unity', since it

\footnotetext{
${ }^{66}$ This idea was brought up by Georg Lichtenberg as an objection to Descartes' cogito, which says that the most that Descartes could claim was 'cogitatur', 'there is some thinking going on'; see Bernard Williams, Descartes, The Project of Pure Enquiry (London: Penguin Books, 1978) 95).

${ }^{67}$ This does not mean that there is only the attribute of thought. This idea rather conjoins the attribute of thought, the mental, and the attribute of extension, the physical, on the basis of the divine mind that infinitely parallels these realms, if rightly put, of these two main attributes.
} 
shows that the duality in unity is epistemic rather than ontic. While the scope of human knowledge provides an understanding of God in a binary opposition as God and God's thinking at the epistemic level; at the ontic level, there exists one divine mind that is God's thinking, and the knowledge of this existence is only available to God himself through his very thinking.

\section{CONCLUSION}

In this article, I started out by facing the phenomenon that when the literary texts, which have an undeniable potential to reveal the philosophical aspects of Sufism, are examined in a way in which an underlying philosophical system can be extracted from them, we see that there are views that do not completely match the traditional viewpoint. In my case, this traditional viewpoint was associated with Ibn al-'Arabi's and our literary text to examine was The Conference of the Birds by Farid ud-Din Attar. My project aimed to work out a sample case (Attar's) and suggest a way of understanding the metaphysical assumptions behind that particular Sufi text. These metaphysical assumptions in Attar's piece seem to systematically match certain pantheistic principles that are in conflict with the traditional viewpoint. The attempt of this article was to cast light on these formal similarities between our interpretation of Attar's text concerning its metaphysical connotations and some elements of the Spinozistic thought. Attar's formulation of the duality in unity and of the totality of the visible and the invisible worlds led me to examine how these assumptions can philosophically survive. After introducing our reading of Spinozistic God as a divine mind, which ontologically includes and consists of an infinite number of thoughts, on the substrate of Spinozistic ideas, I came to relate Attar's Sufi metaphysical assumptions to certain aspects of this reading, in a way in which God's being a single infinite mind captures the Attarian ideas such as 'the duality in unity'. Finally, I suggested that when the metaphysical connotations of The Conference of the Birds are examined in the light of the pantheistic framework suggested earlier, it is seen that reading a Sufi literary text with an interpretation that reflects upon different metaphysical assumptions is plausible. This possibility of there being a different metaphysical reading of at least one Sufi text leads us to think that the traditional approach is not the only recipe for understanding Sufi metaphysics and that the generalisations on Sufi metaphysics are not justified. Sufi literary texts with their philosophy-laden nature await exploration for neoteric interpretations regarding what they have to say about Sufi metaphysics. 


\section{BIBLIOGRAPHY}

Attar, F.-D. [1177]. The Conference of the Birds, translated by Afkham Darbandi and Dick Davis (London: Penguin Books, 1984).

Bennett, J. 'Spinoza's monism: A reply to Curley', in God and Nature: Spinoza's Metaphysics, edited by Y. Yovel (Leiden: E.J. Brill, 1991), 53-60.

Burckhardt, T. Introduction to Sufism (Glasgow: Thorsons, 1995).

Chittick, W. C. The Sufi Path of Knowledge: Ibn al-'Arabi's Metaphysics of Imagination (Albany: State University of New York Press, 1989).

Chittick, W. C. Imaginal Worlds/Ibn al-'Arabi and the Problem of Religious Diversity (Albany: State University of New York Press, 1994).

Curley, E. 'On Bennett's interpretation of Spinoza's monism', in God and Nature: Spinoza's Metaphysics, edited by Y. Yovel (Leiden: Brill, 1991), 35-51.

Haeri, S. F. The Elements of Sufism (Shaftesbury: Element Books, 1990).

Hegel, G. W. F. [1840]. Lectures on the History of Philosophy, translated by R. S. Haldane and Frances H. Simson (London: Routledge \& Kegan Paul; New York: The Humanities Press, 1974).

Jacobi, F. H. [1785]. The Main Philosophical Writings and the Novel Allwill (Montreal: McGill-Queen's University Press, 1994).

Leslie, J. Immortality Defended (Oxford: Blackwell Publishing, 2007).

Lings, M. What is Sufism? (London: Unwin Hyman Limited, 1981).

Lloyd, G. Spinoza and the Ethics (London: Routledge, 1996).

Nicholson, R. A. The Mystics of Islam (England: Arkana, 1989).

Nott, C. S. The Conference of the Birds - A Sufi Fable by Farid ud-Din Attar (Berkeley: Shambala, 1971).

Shah, I. The Way of Sufi (London: Penguin Compass, 1990).

Spinoza, B. [1677]. Ethics, edited and translated by G. H. R. Parkinson (New York: Oxford University Press, 2000).

Steingass, F. J. A Learner's Arabic-English Dictionary (Beirut: Librarie du Liban, 1989).

Stoljar, D. 'Physicalism'. Stanford Encyclopedia of Philosophy. February 2001. Available from: http://plato.stanford.edu/entries/physicalism

Ward, K. Pascal's Fire (Oxford: Oneworld Publications, 2006).

Williams, B. Descartes, The Project of Pure Enquiry (London: Penguin Books, 1978).

Yasukata, T. Lessing's Philosophy of Religion and the German Enlightenment (April 2003, Oxford Scholarship Online Monographs), 117-40. 